BIOORGANIC CHEMISTRY

\title{
Synthesis of 3'- and 3',5'-modified oligonucleotides on functionalized silica "Silochrom-2"
}

\author{
I. Ya. Dubey, L. V. Dubey, D. M. Fedoryak ${ }^{1}$ \\ Institute of Molecular Biology and Genetics, NAS of Ukraine, \\ 150 Zabolotny str., Kyiv, 03143, Ukraine \\ ${ }^{1}$ Institute of Bioorganic Chemistry and Petrochemistry, NAS of Ukraine \\ 1 Murmanska str., Kyiv, 02094, Ukraine \\ dubey@imbg.org.ua
}

\begin{abstract}
The preparation of 3'-mono- and 3', 5'-bis-labeled oligonucleotides on a new fluorescein-functionalized polymer support based on Silochrom-2 microspherical silica is described. Oligonucleotide $(d T)_{15}$ containing a dye residue at 3'-end was synthesized on this support by solid-phase phosphoramidite method. Post-synthetic 5'-modification of 3'-conjugate allowed obtaining double dye-labeled oligomer.
\end{abstract}

Keywords: oligonucleotide conjugates, fluorescent labels, solid-phase synthesis, functionalization.

Introduction. Progress of biotechnology and medicine attracted special attention to conjugates formed by oligonucleotides and molecules with some specific features, i.e. reporting, lipophilic and transport groups, proteins, chemical nucleases, etc. [1-7]. Chemically modified oligonucleotides have been widely used as DNA/RNA-probes, primers for polymerase chain reaction (PCR), in sequencing of nucleic acids (NA), in the investigations of protein-nucleic acid interactions, etc. [1, 6-9]. Non-radioactively labeled oligonucleotides with fluorescent, chemiluminescent, affine or spin reporter groups gradually became the reagents of choice for NA detection. The development of new methods of

(C) I. YA. DUBEY, L. V. DUBEY, D. M. FEDORYAK, 2007 covalent labeling of oligonucleotides and improving the detection sensitivity are still the issues of great importance.

There are two basic approaches to oligonucleotide conjugates preparation [1-5]. The first approach is based on the synthesis and isolation of oligonucleotides functionalized by reactive groups, most commonly amino- or mercaptoalkyl functions, with subsequent attachment of reporter molecules. The second way is based on the direct introduction of reporter group during solid-phase synthesis of oligonucleotide sequence. The key factor in this case is stability of the attached group under conditions of oligonucleotide synthesis and deblocking. The polymer supports containing reporter groups attached via special linkers suitable for synthesizing the nucleotide sequence resulted in the formation of 3 -labeled oligomers have 


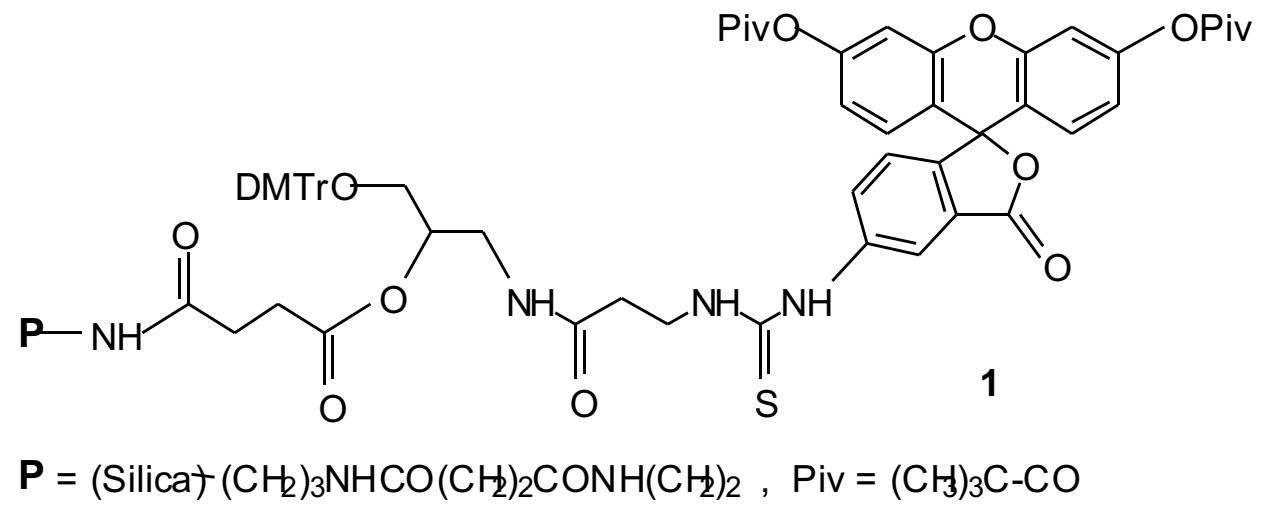

Fig.1 Structure of polymer support used for the synthesis of fluorescein labeled oligonucleotides: Silica - silica gel Silochrom 2 been described. Some of these supports are commercially available from Glen Research, TriLink, Synthegen, Sigma-Genosys, and other companies.

Recently we have obtained fluoresceinfunctionalized polymer support $\mathbf{1}$ based on microspherical aerosilica Silochrom-2 (Fig.1) [10]. This polymer allows performing solid-phase synthesis of fluorescently labeled NA fragments. Current work presents the study on synthesis of mono- and bis-labeled oligonucleotides on this support.

Materials and Methods. The following reagents have been used: 1.1'-carbonyldiimidazole (CDI) and fluorescein-5-isothiocyanate (FITC, isomer I) (Merck, Germany), protected deoxythymidine-3'phosphoramidite and tetrazole for oligonucleotides synthesis, tris(hydroxymethyl)aminomethane, acrylamide and methylene-bis-acrylamide for electrophoresis (Sigma, USA). Other reagents and solvents were purchased from Macrochim, Ukraine. Acetonitrile was distilled over $\mathrm{P}_{2} \mathrm{O}_{5}$ and calcium hydride, dioxane was distilled from $\mathrm{NaOH}$. Synthesis of polymer 1 was performed in accordance with [10]. Absorption spectra were recorded on Shimadzu UV-3100 spectrophotometer (Shimadzu, Japan).

Synthesis of oligonucleotide conjugates with fluorescein Solid-phase synthesis of oligonucleotide $(\mathrm{dT})_{15}$ was performed on polymer 1 on $0.25 \mathrm{mkmol}$ scale by standard phosphoramidite method using Applied Biosystems Model 381A synthesizer. The time of coupling reaction was increased to $5 \mathrm{~min}$ at the step of the first nucleotide component addition. On completion of the sequence synthesis and final 5'-detritylation, polymer support was separated into two parts which were used for the preparation of two different fluorescein conjugates.

To obtain 3'-labelled oligomer 2, after synthesis of $(\mathrm{dT})_{15}$ the polymer was treated with conc. $\mathrm{NH}_{4} \mathrm{OH}(1 \mathrm{ml}$, $50^{\circ} \mathrm{C}, 6 \mathrm{~h}$ ). Deblocked product was obtained by desalting of ammonia solution on PD-10 column (Pharmacia, Sweden), $0.05 \mathrm{M}$ triethylammonium bicarbonate buffer (TEAB, pH 7.8) was used as eluent. Conjugate 2 was purified by electrophoresis in $20 \%$ polyacrylamide gel. UV-Vis: $\mathrm{A}_{260} / \mathrm{A}_{494}=2.04$.

To synthesize oligomer with two terminal fluorescent groups, after the completion of $(\mathrm{dT})_{15}$ sequence elongation aminoalkyl group was introduced at the 5'-end of oligonucleotide linked to the polymer support, using carbonyldiimidazole method [11]. Detritylated polymer was treated with $1 \mathrm{ml}$ of $0.3 \mathrm{M}$ CDI solution in dry dioxane for $45 \mathrm{~min}$, washed with dioxane $(5 \times 1 \mathrm{ml})$, and then treated with $1 \mathrm{ml}$ of $0.2 \mathrm{M}$ solution of hexamethylenediamine in the dioxane-water mixture (9:1) for $45 \mathrm{~min}$. Polymer was washed with dioxane $(3 \times 1 \mathrm{ml})$, methanol $(3 \times 1 \mathrm{ml})$, and ether $(3 \times 1 \mathrm{ml})$. Oligonucleotide 3 containing fluorescein residue at 3 '-end and aliphatic amino group at 5 '-end was cleaved from the polymer and deblocked by the treatment of support with concentrated ammonia, desalted and isolated by gel electrophoresis as described above. Amino-modified oligomer 3 moves in gel slower than non-functionalized conjugate 2. 5 -Aminoalkylated conjugate $3\left(3 \mathrm{~A}_{260}, \sim 21 \mathrm{nmol}\right)$ was treated with FITC in the mixture of $0.1 \mathrm{M}$ carbonate-bicarbonate buffer $(\mathrm{pH}$ 9.5) and 
dimethylformamide $(2: 1)$ using the modified method [12]. FITC solution in DMF $(10 \mathrm{mg} / \mathrm{ml}, 75$ eq. of the reagent to oligonucleotide) was added to oligomer 3 solution in aqueous buffer and kept overnight at room temperature. Conjugate product was separated from the excess of non-bound dye by gel filtration. Reaction mixture was diluted with two volumes of water and applied on a column (PD-10) equilibrated with $0.05 \mathrm{M}$ TEAB-buffer ( $\mathrm{pH} 7.8$ ) containing $5 \% \mathrm{CH}_{3} \mathrm{CN}$. Elution was performed using the same buffer. Double labeled conjugate 4 was purified by gel electrophoresis. Oligomer with two reporter groups moves slower in the gel than the mono-labeled analogue. The yield of conjugate 4 was $1.4 \mathrm{~A}_{260}(\sim 8.5 \mathrm{nmol}, 40 \%)$. UV-Vis: $\mathrm{A}_{260} / \mathrm{A}_{494}=1.18$.

Results and Discussion. A number of supports for the synthesis of oligonucleotides modified with fluorescent dyes, including fluorescein, rhodamine etc., are described in literature [13-17]. The preparation of polymer supports for synthesis of 3'-labeled oligonucleotides requires a bifunctional linker which allows simultaneous attachment of both reporter group and oligonucleotide. Generally, linker structures are based on 2-substituted 1,3-propanediol syntons. We used similar structure of 3-aminopropane-1,2-diol for linker synthesis. The linker was introduced into highly efficient support based on microspherical silica gel Silochrom-2 containing aminopropyl-succinateethylenediamine spacer [18]. As a result fluorescein-modified polymer $\mathbf{1}$ has been obtained (Fig.1) [10]. The support contained fluorescein residue protected with two pivaloyl groups in order to avoid side reaction on phenolic hydroxyl of the dye [13, 19, 20]. Diacylated fluorescein lactone is deblocked easily with the formation of normal dye quinoid structure during amonolysis.

Model pentadecathymidylate $(\mathrm{dT})_{15}$ was synthesized on polymer $\mathbf{1}$ using traditional phosphoramidite chemistry. First coupling reaction time was longer than those on subsequent stages of synthesis ( $5 \mathrm{~min} v s .2 \mathrm{~min}$ ). Prolongation of the first nucleotide addition is recommended for the synthesis on modified polymers with large reporter molecules attached. In this case, negative effect of steric factor is compensated. The yield of the first coupling reaction was $96 \%$ and the yields of the subsequent condensations exceeded $98 \%$.

To obtain 3'-fluorescein derivative $\mathbf{2}$, on sequence completion the oligonucleotide was cleaved from the polymer and deblocked by amonolysis, and then conjugate $\mathbf{2}$ was purified by electrophoresis in polyacrylamide gel (Scheme). Fluorescein-containing oligonucleotides are easily detected in the gel by yellowish-green fluorescence under longwave UV irradiation $(365 \mathrm{~nm})$. Dye containing oligomers are less mobile in the gel comparing to non-modified ones.

Significant amount of non-fluorescent oligomeres was detected in the reaction mixture formed during $(\mathrm{dT})_{15}$ synthesis on polymer $\mathbf{1}$. Perhaps this is due to the fact that during the synthesis of polymer 1 the coupling of the dye to O-DMTr-protected amino linker was not quantitative (DMTr group and fluorescein contents in the polymer were 38 and $28 \mathrm{mkmol} / \mathrm{g}$, respectively [10]), therefore a part of oligonucleotide sequences was synthesized on the linker which did not contain the dye. However, electrophoretic separation of fluorescein-modified oligomeres from non-modified sequences is fully efficient due to different mobilities of labeled and non-labeled products. The introduction of aminoalkyl group at the 5 '-end decreases the mobility of oligomeres additionally.

The attachment of the second reporter group to the 5'-end of 3'-conjugates is possible [13-15, 21-23]. Numerous examples of double-labeled oligonucleotides have been reported. For example, double dye labeled oligomeres use the effect of fluorescence resonance energy transfer (FRET) between donor and acceptor chromophores for homogeneous NA detection, PCR fragments analysis, etc. [8, 24 - 30]. Elegant technology for NA hybridization detecting in the solution uses so called "molecular beacons" - oligonucleotides capable of forming hairpin structures modified by spatially close terminal fluorophore and a quencher group. Hybridization of such probe with complementary NA leads to the separation of dyes resulting in fluorescence increase [31]. There are also some other technologies for NA detection based on similar principles (Scorpions, Sunrise primers, LUX primers, etc.). Corresponding labeled oligonucleotides are known by a common name - light-up probes, whose fluorescence 


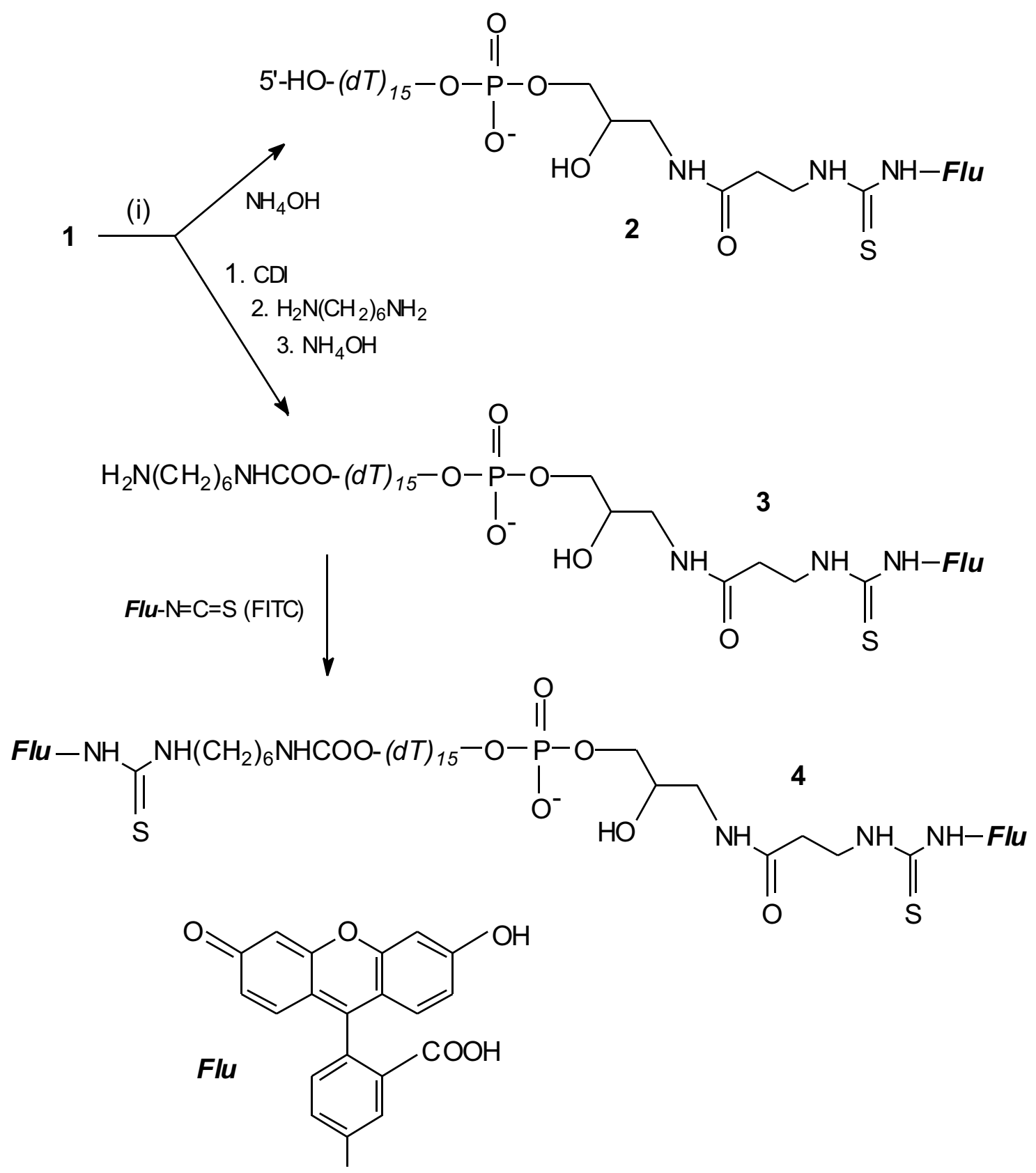

Scheme. Synthesis of mono- and bis-labeled oligonucleotides

increases upon binding to NA targets $[28,32]$. The custom synthesis of double-labeled oligonucleotides is currently available, however, they are very expensive (for $0.2 \mathrm{mkmol}$ scale synthesis the price varies in the range \$300-600, depending on the type of labels).

Second reporter group may be introduced directly during solid-phase synthesis, using phosphoramidite or $\mathrm{H}$-phosphonate derivatives of labels to be attached
[2-5]. We have performed post-synthetic modification by linking aminohexyl group to the 5'-end of oligomer 2 at the first step and isolating functionalized oligonucleotide 3 containing dye at the 3'-end. 5' -Aminoalkyl group was introduced using carbonyldiimidazole method, which consists in the treatment of the protected oligonucleotide linked to the polymer with CDI and then with 


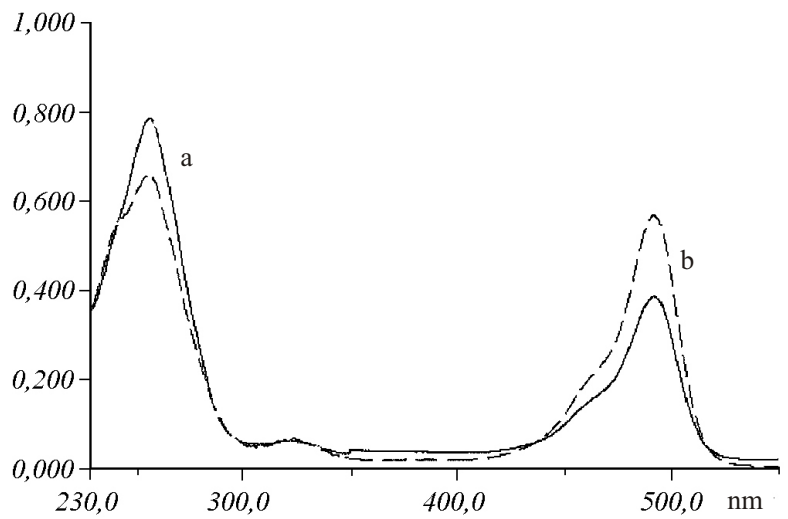

Fig.2 Absorption spectra of oligonucleotide conjugates in 0.05 M TEAB (pH 8): $a-(\mathrm{dT})_{15}$-Flu (2); b-Flu-(dT) $)_{15}$-Flu (4)

hexamethylenediamine [11]. Oligomer 3 was isolated by gel electrophoresis after deblocking. Functionalized conjugate 3 reacted with classic FITC in aqueous-organic medium at $\mathrm{pH} 9.5$ [12]. 75-Fold excess of the dye over oligonucleotide was used. The second fluorophore was attached to oligomer $\mathbf{3}$ under these conditions almost quantitatively, according to HPLC data, with the formation of double labeled (dT) $)_{15}$.

Therefore, model oligonucleotide 4 containing two fluorescein residues at 3'- and 5'-ends was synthesized. The yield of product 4 after electrophoresis purification was about $40 \%$. These bis-labeled oligonucleotides may be applied as more sensitive, comparing to mono-labeled analogues, fluorescent NA probes.

Fluorescein-modified oligonucleotides were desalted on Sephadex G-25 using gel filtration (PD-10 column, Pharmacia) in $0.05 \mathrm{M}$ TEAB buffer, $\mathrm{pH}$ 7.8. The presence of small amount of organic solvent in eluent $(3-5 \%$ acetonitrile or ethanol) decreases non-specific sorption of products on Sephadex, especially when isolating double-labeled oligonucleotides.

UV-Vis spectra of conjugates 2 and 4 (Fig.2) clearly demonstrate the presence of one or two fluorescein residues. Oligonucleotide part does not adsorb in the visible region of the spectrum where the intensive band of dye is observed $\left(\lambda_{\max }=494 \mathrm{~nm}\right)$, however, in the UV region (260 $\mathrm{nm}$ area) both heterocyclic bases of nucleotides and the dye adsorb. Extinction coefficient $\varepsilon_{260}$ is $122000 \mathrm{M}^{-1} \mathrm{~cm}^{-1}$ for $(\mathrm{dT})_{15}$ (calculated using method [33]). Literature data on extinction coefficients of fluorescein within conjugates vary slightly which is due to the dependence of adsorption of this dye (especially in the visible region of the spectrum) on $\mathrm{pH}$ and some other factors [34]. After covalent attachment of the dye, its adsorption in the visible area of the spectrum decreases by $10 \%$ in average [35]. According to [35], in the basic medium fluorescein (as FITC derivative) extinction coefficients are $\varepsilon_{260}=13700$ and $\varepsilon_{494}=68000 \mathrm{M}^{-1} \mathrm{~cm}^{-1}$. According to [36], these coefficients are 20900 and $73000 \mathrm{M}^{-1} \mathrm{~cm}^{-1}$, respectively.

Theoretical ratios of conjugate adsorption intensities in UV and visible areas $\mathrm{A}_{260} / \mathrm{A}_{494}$, calculated using the data from [35], are 2.00 and 1.10 for monoand bis-labeled (dT) ${ }_{15}$, and according to [36] - 1.96 and 1.12 , respectively. These values are in good agreement with experimental data for conjugates $\mathbf{2}$ and $\mathbf{4}\left(\mathrm{A}_{260} / \mathrm{A}_{494}\right.$ are 2.04 and 1.18 respectively).

Therefore, the synthesis of oligonucleotide conjugates with one and two fluorophores is described. Polymer 1 was used as the support for direct solid-phase synthesis of 3'-fluorescein derivative of $(\mathrm{dT})_{15}$, whereas 5 -end functionalization of the obtained conjugate results in obtaining of oligomers with two reporter groups. The method is also suitable for the preparation of oligomeres containing two different fluorescein labels. Almost any reporter molecule can be attached to conjugate 3 using corresponding derivative capable of selective modification of amino groups. There is a possibility to obtain oligomers with terminal modifications of two different types, e.g. 3'-fluorescein labeled oligonucleotide 5'-conjugates with peptides, chemical nucleases or other molecules.

И. Я. Дубей, Л. В. Дубей, Д. М. Федоряк

Синтез 3'- и 3',5'-модифицированных олигонуклеотидов на функционализированном силикагеле "Силохром-2"

Резюме

Описано получение 3'-моно- и 3',5'-бис-меченных олигонуклеотидов на новом полимерном носителе с использованием микросферического силикагеля “Силохром2”, функиионализированном флуоресиеином. На этом полимере твердофазным фосфитамидным методом синтезирован олигонуклеотид $(d T)_{15}$, содержащий остаток красителя на 3 '-конце. Постсинтетическая 5'-модификация 3'-конъюгата позволила получить олигомер, меченный двумя молекулами флуоресиеина. В будущем это будет использовано для синтеза флуоресиентных зондов для детекиии нуклеиновых кислот.

Ключевые слова: олигонуклеотидные конъюгаты, флуоресиентные метки, твердофазный синтез, функиионализация. 


\section{REFERENCES:}

1.Goodchild J. Conjugates of oligonucleotides and modified oligonucleotides: a review of their synthesis and properties // Bioconjugate Chem.-1990.-1.-P. 165-187.

2.Beaucage S. L., Iyer R. P. The functionalization of oligonucleotides via phosphoramidite derivatives // Tetrahedron.-1993.—49.-P. 1925-1963.

3.Protocols for oligonucleotide conjugates: synthesis and analytical techniques // Methods in molecular biology / Ed. S. Agrawal.-Totowa: Humana press, 1993.-Vol. 26. - 390 p.

4.Коршун В. А., Берлин Ю. А. Введение нерадиоактивных репортерных групп в синтетические олигонуклеотиды и их детекция // Биоорг. химия.-1994.-20, № 6.-С. 565-616.

5.Synthesis of modified oligonucleotides and conjugates // Current Protocols in Nucleic Acid Chemistry / Eds S. L Beaucage et al.-New York: John Wiley \& Sons, 2003.-P. 4.0.1 - 4.9.28.

6.Reese C. B. Oligo- and poly-nucleotides: 50 years of chemical synthesis // Org. Biomol. Chem.-2005.-3.-P. 3851-3868.

7.Da Ros T., Spalluto G., Prato M., Saison-Behmoaras T., Boutorine A., Cacciari B. Oligonucleotides and oligonucleotide conjugates: a new approach for cancer treatment // Curr. Med. Chem._2005.—12.-P. $71-88$.

8.Millar D. P. Fluorescence studies of DNA and RNA structure and dynamics // Curr. Opin. Struct. Biol.-1996. - 6.-P. 322-326.

9.The Handbook-A guide to fluorescent probes and labeling technologies // Invitrogen-Molecular Probes / Ed. R. P. Haughland.-Eugene, 2005.-1136 p.

10.Dubey L. V., Dubey I. Y. Preparation of bifunctiomal silica polymer support for the synthesis of 3'-labeled oligonucleotides // Біополімери і клітина.-2005.-21, № 4.-С. 365-369.

11.Wachter L., Jablonski J., Ramachandran K. L. A simple and efficient procedure for the synthesis of 5'-aminoalkyl oligonucleotides // Nucl. Acids Res.-1986.-14.-P. 7985-7994.

12.Agrawal S., Christodoulou C., Gait M. J. Efficient methods for attaching non-radioactive labels to the 5' ends of synthetic oligodeoxyribonucleotides // Nucl. Acids Res.-1986.-14.-P. $6227-6245$.

13.Theisen P., McCollum C., Upadhya K., Jacobson K., Vu H., Andrus A. Fluorescent dye phosphoramidite labelling of oligonucleotides // Tetrahedron Lett.-1992.-33.-P. 5033-5036.

14.Mullah B., Andrus A. Automated synthesis of double dye-labeled oligonucleotides using tetramethylrhodamine (TAMRA) solid supports // Tetrahedron Lett.-1997.-38.-P. 5751-5754.

15.Mullah B., Livak K., Andrus A., Keney P. Efficient synthesis of double dye-labeled oligodeoxyribonucleotide probes and their application in a real time PCR assay // Nucl. Acids Res.-1998.-26.-P. 1026-1031.

16.Korshun V. A., Balakin K. V., Proskurina T. S., Mikhalev I. I., Malakhov A. D., Berlin Y. A. A pyrene secopseudonucleoside in constructing interaction-sensitive fluorescent DNA probes // Nucleosides and Nucleotides.-1999.-18.-P.2661-2676.

17. Stetsenko D. A., Gait M. J. A convenient solid-phase method for synthesis of 3'-conjugates of oligonucleotides // Bioconjugate Chem-2001-12 - P. 576-586.

18.Дубей И. Я., Ляпина Т. В., Федоряк Д. М. Микросферический аэросилогель “Силохром-2"-высокоэффективный носитель для твердофазного синтеза олигонуклеотидов // Биоорг. химия.-1993.-19, № 5.—С. 589-592.
19.Behrens C., Dahl O. Synthesis of achiral linker reagents for direct labelling of oligonucleotides on solid supports // Nucleosides and Nucleotides.-1999.-18.-P. 291-305.

20.Laurent A., Debart F., Lamb N., Rayner B. Esteraze-triggered fluorescence of fluorogenic oligonucleotides // Bioconjugate Chem.-1997.-8.-P. 856-861.

21.Agrawal S., Zamecnik P. C. Site specific functionalization of oligonucleotides for attaching two different reporter groups // Nucl. Acids Res.-1990.-18.-P. 5419-5423.

22.Kahl J. D., McMinn D. L., Greenberg M. M. High-yielding method for on-column derivatization of protected oligodeoxynucleotides and its application to the convergent synthesis of 5', 3'-bis-conjugates // J. Org. Chem.-1998. -63.-P. 4870-4871.

23.Dubey I., Pratviel G., Meunier B. Modification of the thiourea linkage of fluorescein-oligonucleotide conjugate to a guanidinium motif during ammonia deprotection // Bioconjugate Chem.-1998.-9.-P. 627-632.

24.Ju J., Ruan C., Fuller C. W., Glazer A. N., Mathies R. A. Fluorescence energy transfer dye-labeled primers for DNA sequencing and analysis // Proc. Nat. Acad. Sci. USA.-1995.-92.-P. $4347-4351$.

25.Glazer A. N., Mathies R. A. Energy-transfer fluorescent reagents for DNA analyses // Curr. Opin. Biotechnol.-1997.-8.-P. 94-102.

26.Okamura Y., Kondo S., Sase I., Suga T., Mise K., Furusawa I., Kawakami S., Watanabe Y. Double-labeled donor probe can enhance the signal of fluorescence resonance energy transfer (FRET) in detection of nucleic acids hybridization // Nucl. Acids Res.-2000.-28.-P. e107.

27.Yamane A. MagiProbe: a novel fluorescence quenching-based oligonucleotide probe carrying a fluorophore and intercalator // Nucl. Acids Res.-2002.-30.-P. e97.

28.Wong M. L., Medrano J. F. Real-time PCR for mRNA quantitatiom // BioTechniques.-2005.-39.-P. 75-85.

29. Metzker M. L. Emerging technologies in DNA sequencing // Genome Res.-2005.-15.-P. 1767-1776.

30.Dirks R. W., Tanke H. J. Advances in fluorescent tracking of nucleic acids in living cells // BioTechniques._-2006._40.-P. 489-496.

31.Tyagi S., Kramer F. R. Molecular beacons-probes that fluoresce upon hybridization // Nat. Biotechnol.-1996.—14.-P. 303-308.

32.Isacsson J., Cao I., Ohlson L., Nordgren S., Svanvik N., Westmen G., Kubista M., Sjoback R., Sehlstedt U. Rapid and specific detection of PCR products using light-up probes // Mol. Cell Probes.-2000.-17.-P. 321-328.

33. Handbook of Biochemistry and Molecular Biology / Ed. G. Fasman.-Boca Raton: CRC press, 1975.-Vol. 1.-175 p.

34.Sjoback R., Nygren J., Kubista M. Characterization of fluorescein-oligonucleotide conjugates and measurement of local electrostatic potential // Biopolymers.-1998. - 46.-P. 445-453.

35.Glen Research Product http://www.glenres.com/index.htmli/ProductFiles/10-1963.html

36.Edelman L. M., Cheong R., Kahn J. D. Fluorescence resonance energy transfer over $\sim 130$ basepairs in hyperstable Lac repressor-DNA loops // Biophys. J.-2003.-84.-P. 1131-1145.

Надійшла до редакці1 26.10 .06 